\title{
Chryseobacterium oranimense sp. nov., a psychrotolerant, proteolytic and lipolytic bacterium isolated from raw cow's milk
}

\author{
Elionora Hantsis-Zacharov, ${ }^{1}$ Tamar Shakéd, ${ }^{2}$ Yigal Senderovich ${ }^{1}$ \\ and Malka Halpern ${ }^{1,2}$
}

Correspondence

Malka Halpern

mhalpern@research.haifa.ac.il

\author{
${ }^{1}$ Department of Evolutionary and Environmental Biology, Faculty of Science and Science Education, \\ University of Haifa, Mount Carmel, Haifa 31905, Israel \\ ${ }^{2}$ Department of Biology Education, Faculty of Science and Science Education, University of Haifa, \\ Oranim, Tivon 36006, Israel
}

\begin{abstract}
A Gram-negative, rod-shaped, oxidase-positive, aerobic, non-motile and orange-pigmented bacterial strain, containing flexirubin-type pigments, designated $\mathrm{H}^{\top}$, was isolated from raw cow's milk in Israel. 16S rRNA gene sequence analysis indicated that the isolate should be placed in the genus Chryseobacterium (family Flavobacteriaceae, phylum Bacteroidetes). The levels of $16 \mathrm{~S}$ rRNA gene sequence similarity between strain $\mathrm{H}^{\top}$ and the type strains of described Chryseobacterium species were $97.5 \%$ or lower. Strain $\mathrm{H}^{\top}$ grew at $5-37{ }^{\circ} \mathrm{C}$ and with $0-3.0 \%$ $\mathrm{NaCl}$. The dominant cellular fatty acids were iso-15:0, iso-17:0 3-OH, iso-17:1 $19 \mathrm{c}$ and summed feature 3 (comprising iso-15:0 2-OH and/or $16: 1 \omega 7 \mathrm{c}$ ). On the basis of phenotypic properties and phylogenetic distinctiveness, the milk isolate $\mathrm{H}^{\top}$ is classified as a member of a novel species in the genus Chryseobacterium, for which the name Chryseobacterium oranimense sp. nov. (type strain $\mathrm{H}^{\top}=\mathrm{LMG} 24030^{\top}=\mathrm{DSM} 19055^{\top}$ ) is proposed.
\end{abstract}

The genus Chryseobacterium (Vandamme et al., 1994) is a member of the family Flavobacteriaceae, phylum Bacteroidetes, and currently consists of 25 species, with Chryseobacterium gleum as the type species. Strains belonging to this genus occur in a variety of ecological niches such as water, soil, plants and the clinical environment (Bernardet et al., 2002, 2005, 2006; Park et al., 2006). They are also a part of the psychrotolerant and proteolytic bacterial population that causes a variety of defects in food products such as milk, meat, poultry and fish (González et al., 2000; Hugo et al., 1999, 2003; de Beer et al., 2005, 2006; Hantsis-Zacharov \& Halpern, 2007a, b; Hantsis-Zacharov et al. 2008).

Strain $\mathrm{H} 8{ }^{\mathrm{T}}$ was isolated in April 2004 in the course of a study on the diversity of culturable psychrotolerant bacteria in raw milk (Hantsis-Zacharov \& Halpern, 2007b). Raw milk samples were serially diluted and plated on sterile standard plate count (SPC) agar (Oxoid CM0463). Plates were incubated at $7{ }^{\circ} \mathrm{C}$ for 10 days and colonies that displayed distinct morphologies were subcultured to obtain pure cultures. A comparative analysis of $16 \mathrm{~S}$ rRNA gene sequences indicated that strain $\mathrm{H}^{\mathrm{T}}$ was a member of the genus

The GenBank/EMBL/DDBJ accession number for the $16 \mathrm{~S}$ rRNA gene sequence of strain $\mathrm{H}^{\top}{ }^{\top}$ is EF204451.
Chryseobacterium. In order to determine its exact taxonomic position, a polyphasic taxonomic study was carried out.

The universal bacterial primers $8 \mathrm{f}$ and 1512r (based on Escherichia coli positions) were used to amplify internal fragments of the 16S rRNA gene according to Felske et al. (1997). PCR products (approx. $1.5 \mathrm{~kb}$ ) were purified using an AccuPrep PCR purification kit (Bioneer; http:// www.bioneer.co.kr). Purified PCR products were sequenced at Technion Medical School (Haifa, Israel) directly by the dideoxynucleotide chain-termination method using a DNA sequencer (ABI PRISM 3100) with BigDye terminator reagents (Applied Biosystems) according to the manufacturer's instructions. Sequencing was performed by using the primers of (5'-GGATCCAGAC TTTGATYMTGGCTCAG-3'), 534r (5'-ATTACCGCGGC TGCTGG-3' $), \quad 968 \mathrm{f} \quad\left(5^{\prime}\right.$-AACGCGAAGAACCTTAC-3') and 1512f (5'-GTGAAGCTTACGGYTAGCTTGTTACG ACTT-3'). The newly determined sequence was compared to those available in GenBank (http://www.ncbi.nlm.nih. gov) using the BLAST program (version 2.0). Phylogenetic and molecular evolutionary analyses were conducted using MEGA version 4 (Tamura et al. 2007).

The $1453 \mathrm{bp}$ sequence of strain $\mathrm{H} 8^{\mathrm{T}}$ shared highest sequence similarity of $97.5 \%$ with Chryseobacterium joostei LMG $18212^{\mathrm{T}}, 97.2 \%$ with Chryseobacterium shigense 


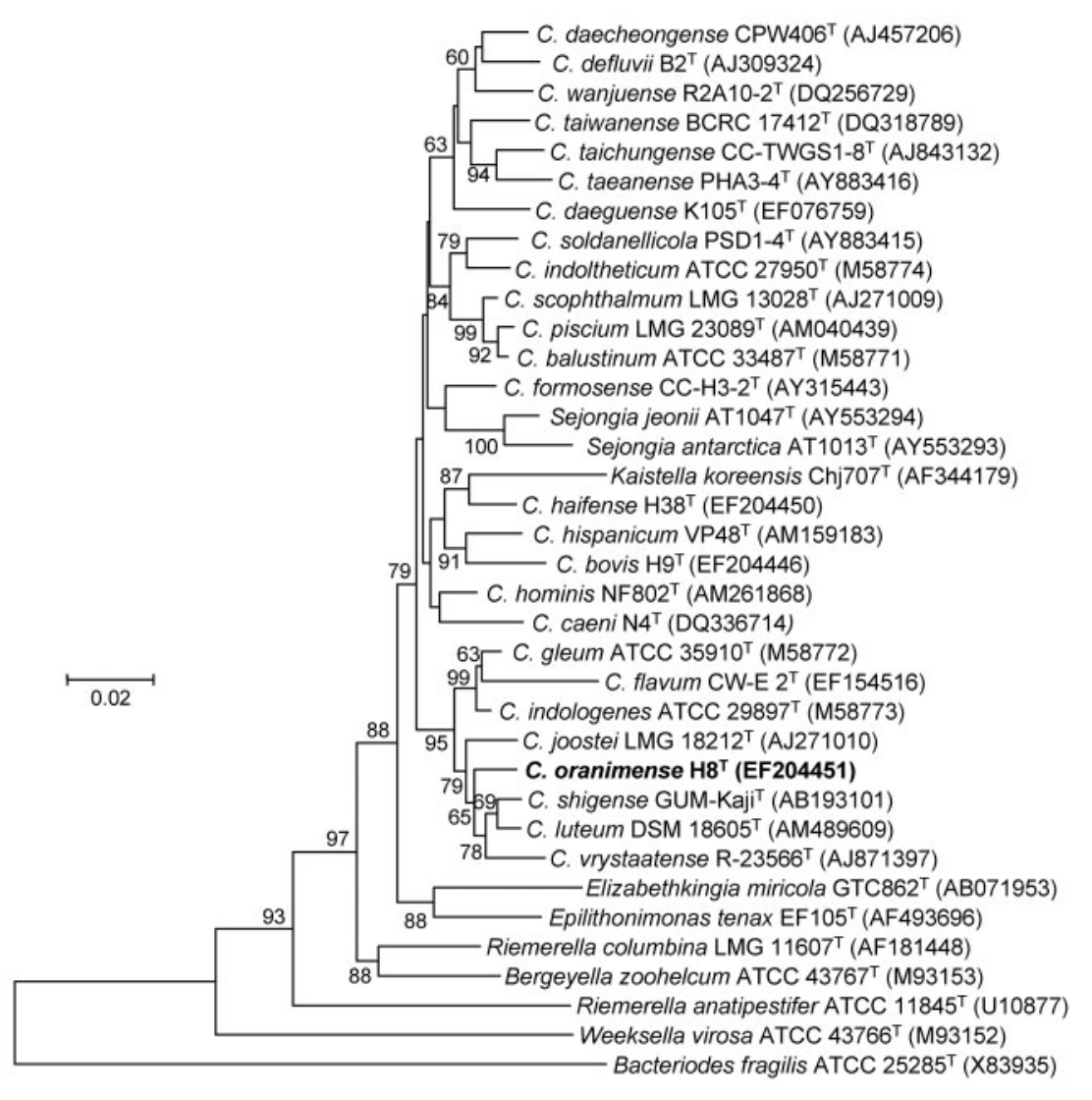

Fig. 1. Neighbour-joining dendrogram of $16 \mathrm{~S}$ rRNA gene sequences obtained from strain $\mathrm{H}^{\top}$ and related species and genera. The $16 \mathrm{~S}$ rRNA gene sequence of Bacteroides fragilis ATCC $25285^{\top}$ was used as an outgroup. Bootstrap values (>50\%) resulting from 1000 replicates are indicated at branching nodes. Bar, 0.02 substitutions per nucleotide position.
GUM-Kaji $^{\mathrm{T}}$ and $<97.0 \%$ with the type strains of all other Chryseobacterium species (Fig. 1).

DNA-DNA hybridization studies between strain $\mathrm{H} 8^{\mathrm{T}}$ and strains of other Chryseobacterium species were not carried out, as strains exhibiting a difference of $2.5 \%$ or more at the $16 \mathrm{~S}$ rRNA gene sequence level are unlikely to share more than $70 \%$ DNA-DNA relatedness (Stackebrandt \& Goebel, 1994). Moreover, a new threshold (of $1.3 \%$ difference) has recently been suggested by Stackebrandt \& Ebers (2006).

For electron microscopy, bacteria grown on SPC agar $\left(48 \mathrm{~h}, 32{ }^{\circ} \mathrm{C}\right)$ were suspended in saline, fixed to a carboncoated grid, stained with $2 \%$ uranyl acetate and photographed using a JEM-1200EX electron microscope (JEOL).

For phenotypic characterization, Luria-Bertani (LB) agar was used as the basal growth medium. Salt tolerance was determined at $30{ }^{\circ} \mathrm{C}$ on LB agar containing $0-5 \%(\mathrm{w} / \mathrm{v})$ $\mathrm{NaCl}$ at $1 \%$ intervals. Growth was measured on SPC agar at $5,7,10,14,17,25,30,33,37,40$ and $45^{\circ} \mathrm{C}$. The $\mathrm{pH}$ range for growth was determined using LB broth adjusted to $\mathrm{pH} 4.0-10.0$ at $2 \mathrm{pH}$ unit intervals. The $\mathrm{pH}$ was adjusted prior to sterilization by the addition of $\mathrm{HCl}$ or $\mathrm{NaOH}$ and measured again after sterilization. Growth under anaerobic conditions was determined after incubation in a BBL GasPak anaerobic jar (Becton Dickinson) with approximately $4-10 \% \mathrm{CO}_{2}$ on LB agar supplemented with $0.5 \%$ $(\mathrm{w} / \mathrm{v})$ glucose or $0.1 \%(\mathrm{w} / \mathrm{v})$ potassium nitrate.
Biochemical tests were performed by using API 20E, API 20NE, API $50 \mathrm{CH}$ and API ZYM identification systems (bioMérieux) according to the manufacturer's instructions, except that the incubation temperature was $32{ }^{\circ} \mathrm{C}$. Catalase activity was detected by bubble production in a $3 \%(\mathrm{v} / \mathrm{v})$ hydrogen peroxide solution. Oxidase activity was determined using $1 \% N, N, N^{\prime}, N^{\prime}$-tetramethyl-p-phenylenediamine dihydrochloride (Sigma-Aldrich). Growth was tested on MacConkey agar (Difco) and cetrimide agar (Himedia). Hydrolysis of casein and tributyrin was determined using $1 \%$ skimmed milk agar supplemented with $0.5 \%$ yeast extract and tributyrin agar (Hylabs), respectively. Hydrolysis of starch was determined using plates containing soluble starch $(1 \%)$, beef extract $(0.3 \%)$ and agar (2\%). DNase activity was tested on DNase test agar with methyl green (Difco). The phenotypic traits of the isolate are given in the species description and in Table 1.

The cell mass of strain $\mathrm{H}^{\mathrm{T}}{ }^{\mathrm{T}}$ was subjected to the $\mathrm{KOH}$ test as described by Fautz \& Reichenbach (1980) and Bernardet et al. (2002). A colour change was observed, demonstrating that flexirubin-type pigments are produced. As two type strains of the genus Chryseobacterium were found to possess carotenoids when grown under light conditions (Hantsis-Zacharov \& Halpern, 2007a; Hantsis-Zacharov et al., 2008), the production of carotenoid-type pigments of strain $\mathrm{H} 8{ }^{\mathrm{T}}$ was also investigated. The yellow pigments were extracted and investigated according to Peterson et al. 


\section{Table 1. Differentiating characteristics of Chryseobacterium species}

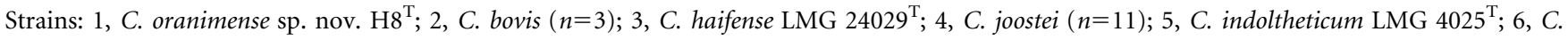
scophthalmum ( $n=7) ; 7$, C. defluvii DSM $14219^{\mathrm{T}} ; 8$, C. gleum $(n=12) ; 9$, C. daecheongense DSM 15235 ${ }^{\mathrm{T}}$; 10, C. formosense CCUG 49271 ${ }^{\mathrm{T}}$; 11 , C. taichungense CCUG $50001^{\mathrm{T}}$; 12, C. shigense DSM $17126^{\mathrm{T}} ; 13$, C. vrystaatense $(n=36) ; 14$, C. soldanellicola KCTC $12382^{\mathrm{T}} ; 15$, C. taeanense KCTC $12381^{\mathrm{T}}$; 16, C. piscium $(n=4) ; 17$, C. hispanicum CECT $7129^{\mathrm{T}} ; 18$, C. wanjuense DSM $17724^{\mathrm{T}} ; 19$, C. taiwanense BCRC $17412^{\mathrm{T}}$; 20, C. caeni DSM $17710^{\mathrm{T}}$; 21, C. daeguense JCM $14362^{\mathrm{T}} ; 22$, C. balustinum LMG $8329^{\mathrm{T}}$; 23, C. indologenes $(n=13) ; 24$, C. luteum $(n=3) ; 25$, C. flavum KCTC $12877^{\mathrm{T}}$; 26, C. hominis $(n=11)$. The number of strains examined, when greater than 1 , is shown in parentheses. Data were taken from Yabuuchi et al. (1983), Holmes et al. (1984), Hugo et al. (2003), Kämpfer et al. (2003), Kim et al. (2005), Shen et al. (2005), Shimomura et al. (2005), Young et al. (2005), de Beer et al. (2005, 2006), Gallego et al. (2006), Park et al. (2006), Tai et al. (2006), Weon et al. (2006), Quan et al. (2007), Yoon et al. (2007), Hantsis-Zacharov \& Halpern (2007a), Behrendt et al. (2007), Zhou et al. (2007), Vaneechoutte et al. (2007), Hantsis-Zacharov et al. (2008) and this study. +, Positive; w, weakly positive; -, negative; v, variable; NA, no data available.

\begin{tabular}{|c|c|c|c|c|c|c|c|c|c|c|c|c|c|c|c|c|c|c|c|c|c|c|c|c|c|c|}
\hline Characteristic & 1 & 2 & 3 & 4 & 5 & 6 & 7 & 8 & 9 & 10 & 11 & 12 & 13 & 14 & 15 & 16 & 17 & 18 & 19 & 20 & 21 & 22 & 23 & 24 & & 26 \\
\hline $3 \% \mathrm{NaCl}$ & + & - & - & NA & $\mathrm{w}$ & $\mathrm{w}$ & - & $\mathrm{NA}$ & NA & NA & NA & $\mathrm{NA}$ & - & + & + & + & - & - & + & + & - & $\mathrm{w}$ & + & NA & + & - \\
\hline Cetrimide agar & - & - & - & + & - & - & - & - & NA & NA & NA & NA & + & NA & NA & - & NA & NA & NA & NA & NA & - & + & NA & + & - \\
\hline MacConkey agar & + & - & - & + & + & - & - & + & - & - & - & - & - & - & - & - & - & $\mathrm{w}$ & NA & - & - & + & + & - & + & - \\
\hline $37{ }^{\circ} \mathrm{C}$ & + & + & + & - & - & - & + & + & + & + & + & - & - & + & + & - & - & + & + & + & + & + & + & - & + & + \\
\hline $42{ }^{\circ} \mathrm{C}$ & - & - & - & - & - & - & + & - & - & - & - & - & - & - & - & - & - & - & + & - & - & - & + & - & + & - \\
\hline Hydrolysis of casein & + & $\mathrm{v}$ & + & + & + & + & + & + & + & NA & NA & + & NA & NA & $\mathrm{NA}$ & + & + & + & + & NA & + & + & + & $\mathrm{V}$ & + & NA \\
\hline Nitrate reduction & - & $\mathrm{V}$ & - & - & - & - & - & NA & + & - & - & - & - & - & - & + & + & - & - & - & - & + & V & - & - & $\mathrm{V}$ \\
\hline Urease activity & - & - & - & $\mathrm{V}$ & - & + & - & $\mathrm{V}$ & - & - & - & - & + & - & - & + & - & - & - & + & - & - & - & - & - & - \\
\hline $\begin{array}{l}\beta \text {-Galactosidase } \\
\text { activity }\end{array}$ & $+末$ & $\mathrm{~V}$ & + & - & - & + & NA & $\mathrm{V}$ & - & - & $\mathrm{w}$ & NA & NA & - & - & NA & + & + & - & + & - & - & - & + & + & - \\
\hline \multicolumn{27}{|l|}{$\begin{array}{l}\text { Acid production } \\
\text { from: }\end{array}$} \\
\hline Glucose & - & $\mathrm{v}$ & + & + & NA & - & + & + & - & w & $\mathrm{w}$ & + & NA & $\mathrm{NA}$ & $\mathrm{NA}$ & NA & + & + & - & - & + & + & + & + & - & + \\
\hline L-Arabinose & - & - & - & - & - & - & - & + & - & - & - & - & NA & - & - & NA & $\mathrm{NA}$ & - & + & - & $\mathrm{w}$ & NA & V & + & - & - \\
\hline D-Fructose & - & - & + & + & - & - & NA & + & + & NA & NA & + & NA & - & - & NA & + & - & $\mathrm{V}$ & - & + & + & + & + & + & NA \\
\hline Lactose & - & $\mathrm{v}$ & + & - & - & - & NA & - & - & NA & - & - & NA & - & - & NA & - & - & - & - & + & - & - & - & - & - \\
\hline Maltose & - & $\mathrm{v}$ & + & + & + & - & + & + & - & - & + & - & NA & - & - & NA & + & - & - & - & + & - & + & + & + & + \\
\hline D-Mannitol & - & - & - & V & NA & - & - & - & - & - & - & - & NA & - & - & NA & - & - & - & - & - & - & V & - & - & - \\
\hline Trehalose & - & - & - & + & - & - & + & + & + & + & + & - & NA & - & - & NA & - & + & - & - & + & - & + & + & + & - \\
\hline D-Xylose & - & - & - & - & - & - & - & $\mathrm{V}$ & + & w & + & - & NA & - & - & NA & + & - & NA & - & W & - & - & - & + & - \\
\hline
\end{tabular}

${ }^{*}$ The type of yellow pigment (when determined) is indicated by F (flexirubin-type) or C (carotenoid-type).

$\dagger$ Yellow pigments are produced only when bacteria are grown under light conditions.

‡Detected only in API 20NE strips.

(1954). Briefly, the isolate was grown on LB agar at room temperature under light and dark conditions for $48 \mathrm{~h}$. Cells were transferred to acetone, vortexed for $1 \mathrm{~min}$, allowed to stand for $10 \mathrm{~min}$ and then centrifuged for $3 \mathrm{~min}$ at 13000 r.p.m. Spectral analysis from 400 to $700 \mathrm{~nm}$ was performed on the acetone extract. Strain $\mathrm{H}^{\mathrm{T}}$ did not contain carotenoid-type pigments.

For cellular fatty acid analysis, strain $\mathrm{H}^{\mathrm{T}}$ was cultured on tryptic soy agar (Difco) for $24 \mathrm{~h}$ at $28{ }^{\circ} \mathrm{C}$ and the fatty acids were extracted and methylated (Ben-Ze'ev et al., 2005). Fatty acid methyl esters were analysed by gas chromatography using the MIDI/Hewlett Packard microbial identification system (Analytical Services Inc.). The major fatty acids $(>10 \%)$ of strain $\mathrm{H}^{\mathrm{T}}$ were iso-15: 0 (39.6\%), iso-17: $1 \omega 9 \mathrm{c}$ (20.6\%), iso-17:0 3-OH (18.5\%) and summed feature 3 (comprising iso-15:0 2-OH and/or $16: 1 \omega 7 c ; 10.8 \%$ ). The following fatty acids were present as minor components: iso$15: 0$ 3-OH (3.5\%), iso-17:0 (1.5\%), $16: 0$ (1.2\%), unknown ECL 16.582 (1.1\%) and 16:0 3-OH (1.0\%).

Strain $\mathrm{H}^{\mathrm{T}}$ was isolated when psychrotolerant bacterial communities in raw milk and their proteolytic and lipolytic traits were studied (Hantsis-Zacharov \& Halpern, 2007b). Five per cent of the isolates were members of the genus Chryseobacterium (GenBank accession numbers 
EF204446-EF204459). Four of these isolates have already been described as representatives of two novel Chryseobacterium species, Chryseobacterium haifense and Chryseobacterium bovis (Hantsis-Zacharov \& Halpern, 2007a; Hantsis-Zacharov et al., 2008). Strain $\mathrm{H}^{\mathrm{T}}$ exhibited lipolytic and proteolytic activities. Heat-stable proteolytic and lipolytic enzymes originating from psychrotolerant bacteria are a limiting factor in maintaining the flavour quality of fluid milk and its products. However, the impact of Chryseobacterium isolates and in particular the role of strain $\mathrm{H} 8^{\mathrm{T}}$ on milk quality has yet to be determined.

Being non-motile rods, catalase- and oxidase-positive and containing flexirubin-type pigments, with iso-15:0 and iso17:0 $3-\mathrm{OH}$ as the dominant fatty acids, the new isolate shared the main characteristics of Chryseobacterium strains. However, it differed from described Chryseobacterium species in several phenotypic traits listed in Table 1 . Strain $\mathrm{H}^{\mathrm{T}}$ can be differentiated from its closest relative, Chryseobacterium joostei, which has also been isolated from raw milk (Hugo et al., 2003), by the following characteristics: ability to grow at $37^{\circ} \mathrm{C}$, inability to produce acid from sugars including glucose, production of large amounts of the fatty acid summed feature 3 (comprising iso-15:0 2-OH and/or $16: 1 \omega 7 c, 10.8 \%$ ) and lack of summed feature 4 (iso-17:1 I and/or anteiso-17:1 B). Combinations of phenotypic characteristics also differentiate strain $\mathrm{H}^{\mathrm{T}}$ clearly from the other Chryseobacterium species isolated from raw milk ( $C$. haifense and C. bovis; Table 1).

On the basis of phenotypic characterization and phylogenetic analysis, we propose that isolate $\mathrm{H} 8^{\mathrm{T}}$ be classified as the type strain of a novel species, for which the name Chryseobacterium oranimense sp. nov. is proposed.

\section{Description of Chryseobacterium oranimense sp. nov.}

Chryseobacterium oranimense (o.ra.ni.men'se. N.L. neut. adj. oranimense pertaining to Oranim campus, where the type strain was characterized).

Cells are Gram-negative, non-motile rods, $0.7-1.2 \mu \mathrm{m}$ wide and 1.2-2.0 $\mu \mathrm{m}$ long. After $48 \mathrm{~h}$ of incubation on SPC agar at $32{ }^{\circ} \mathrm{C}$ in the dark, colonies are circular with entire edges, opaque, mucoid and orange-coloured. Flexirubin-type pigments are produced but carotenoid-type pigments are not produced. Growth is not observed under anaerobic conditions. Grows at $5-37{ }^{\circ} \mathrm{C}$ (optimum, $30-33{ }^{\circ} \mathrm{C}$ ), with $0-3.0 \%$ $\mathrm{NaCl}$ (optimum, $0-1.0 \% \mathrm{NaCl}$ ) and at $\mathrm{pH} 4.0-8.0$ (optimum, pH 6.0-8.0). Growth occurs on nutrient, trypticase soy and MacConkey agars but not on cetrimide agar. Catalase and oxidase activities are present. Starch, casein and tributyrin are hydrolysed. DNase activity is present. The following results are obtained from API 20NE strips after $48 \mathrm{~h}$ of incubation at $32{ }^{\circ} \mathrm{C}$ : indole is produced; aesculin and gelatin are hydrolysed; glucose, arabinose, mannose, maltose and citrate are assimilated; adipic and malic acids are assimilated weakly; $\beta$-galactosidase activity is present. The following results are obtained from API 20E strips after $24 \mathrm{~h}$ of incubation at $32{ }^{\circ} \mathrm{C}$ : indole is produced; gelatin is hydrolysed; nitrate is reduced to $\mathrm{N}_{2} ; \mathrm{H}_{2} \mathrm{~S}$ and acetoin are not produced; urea is not hydrolysed; citrate is not utilized; activities of $\beta$-galactosidase, arginine dihydrolase, lysine and ornithine decarboxylases and tryptophan deaminase are absent. In API $50 \mathrm{CH}$ strips incubated for $48 \mathrm{~h}$ at $32{ }^{\circ} \mathrm{C}$, acid is produced from aesculin. In API ZYM strips incubated for $4.5 \mathrm{~h}$ at $32{ }^{\circ} \mathrm{C}$, activities of alkaline and acid phosphatases, esterase (C4), esterase lipase (C8), leucine arylamidase, valine arylamidase, naphthol-AS-BI-phosphohydrolase and $\beta$-glucosidase are present. The dominant cellular fatty acids are iso- $15: 0$, iso- $17: 1 \omega 9 c$, iso- $17: 03-\mathrm{OH}$ and summed feature 3 (comprising iso-15:0 2-OH and/or $16: 1 \omega 7 c$ ). The following fatty acids are present as minor components: iso$15: 03-\mathrm{OH}$, iso-17:0, 16:0, unknown ECL 16.582 and 16:0 $3-\mathrm{OH}$. Traces $(<1 \%)$ of iso-13:0, 14:0, anteiso-15:0, summed feature 4 (comprising iso-17:1 I and/or anteiso$17: 1 \mathrm{~B})$ and $18: 1 \omega 5 \mathrm{c}$ are also present.

The type strain is $\mathrm{H}^{\mathrm{T}}\left(=\mathrm{LMG} 24030^{\mathrm{T}}=\mathrm{DSM} 19055^{\mathrm{T}}\right)$, isolated from raw cow's milk in Israel.

\section{Acknowledgements}

This work was supported by a grant from the Tnuva Research Institute, Israel.

\section{References}

Behrendt, U., Ulrich, A., Spröer, C. \& Schumann, P. (2007). Chryseobacterium luteum sp. nov., associated with the phyllosphere of grasses. Int J Syst Evol Microbiol 57, 1881-1885.

Ben-Ze'ev, I. S., Levy, E., Eilam, T. \& Anikster, Y. (2005). Whole-cell fatty acid profiles - a tool for species and subspecies classification in the Puccinia recondita complex. J Plant Pathol 87, 187-197.

Bernardet, J.-F., Nakagawa, Y. \& Holmes, B. (2002). Proposed minimal standards for describing new taxa of the family Flavobacteriaceae and emended description of the family. Int J Syst Evol Microbiol 52, 1049-1070.

Bernardet, J. F., Vancanneyt, M., Matte-Tailliez, O., Grisez, L., Tailliez, P., Bizet, C., Nowakowski, M., Kerouault, B. \& Swings, J. (2005). Polyphasic study of Chryseobacterium strains isolated from diseased aquatic animals. Syst Appl Microbiol 28, 640-660.

Bernardet, J.-F., Hugo, C. \& Bruun, B. (2006). The genera Chryseobacterium and Elizabethkingia. In The Prokaryotes: a Handbook on the Biology of Bacteria, 3rd edn, vol. 7, pp. 638-676. Edited by M. Dworkin, S. Falkow, E. Rosenberg, K. H. Schleifer \& E. Stackebrandt. New York: Springer.

de Beer, H., Hugo, C. J., Jooste, P. J., Willems, A., Vancanneyt, M., Coenye, T. \& Vandamme, P. A. R. (2005). Chryseobacterium vrystaatense sp. nov., isolated from raw chicken in a chicken processing plant. Int J Syst Evol Microbiol 55, 2149-2153.

de Beer, H., Hugo, C. J., Jooste, P. J., Vancanneyt, M., Coenye, T. \& Vandamme, P. (2006). Chryseobacterium piscium sp. nov., isolated from fish of the South Atlantic Ocean off South Africa. Int J Syst Evol Microbiol 56, 1317-1322.

Fautz, E. \& Reichenbach, H. (1980). A simple test for flexirubin-type pigments. FEMS Microbiol Lett 8, 87-91.

Felske, A., Rheims, H., Wolterink, A., Stackebrandt, E. \& Akkermans, A. D. (1997). Ribosome analysis reveals prominent activity of an 
uncultured member of the class Actinobacteria in grassland soils. Microbiology 143, 2983-2989.

Gallego, V., Garcia, M. T. \& Ventosa, A. (2006). Chryseobacterium hispanicum sp. nov., isolated from the drinking water distribution system of Sevilla, Spain. Int J Syst Evol Microbiol 56, 1589-1592.

González, C. J., Santos, J. A., Garcia-Lopez, M. L. \& Otero, A. (2000). Psychrobacters and related bacteria in freshwater fish. J Food Prot 63, 315-321.

Hantsis-Zacharov, E. \& Halpern, M. (2007a). Chryseobacterium haifense sp. nov., a psychrotolerant bacterium isolated from raw milk. Int J Syst Evol Microbiol 57, 2344-2348.

Hantsis-Zacharov, E. \& Halpern, M. (2007b). Psychrotrophic bacterial communities in raw milk and their proteolytic and lipolytic traits. Appl Environ Microbiol 73, 7162-7168.

Hantsis-Zacharov, E., Senderovich, Y. \& Halpern, M. (2008). Chryseobacterium bovis sp. nov., isolated from raw cow's milk. Int J Syst Evol Microbiol 58, 1024-1028.

Holmes, B., Owen, R. J., Steigerwalt, A. G. \& Brenner, D. J. (1984). Flavobacterium gleum, a new species found in human clinical specimens. Int J Syst Bacteriol 34, 21-25.

Hugo, C. J., Jooste, P. J., Segers, P., Vancanneyt, M. \& Kersters, K. (1999). A polyphasic taxonomic study of Chryseobacterium strains isolated from dairy sources. Syst Appl Microbiol 22, 586-595.

Hugo, C. J., Segers, P., Hoste, B., Vancanneyt, M. \& Kersters, K. (2003). Chryseobacterium joostei sp. nov., isolated from the dairy environment. Int J Syst Evol Microbiol 53, 771-777.

Kämpfer, P., Dreyer, U., Neef, A., Dott, W. \& Busse, H.-J. (2003). Chryseobacterium defluvii sp. nov., isolated from wastewater. Int J Syst Evol Microbiol 53, 93-97.

Kim, K. K., Bae, H.-S., Schumann, P. \& Lee, S.-T. (2005). Chryseobacterium daecheongense sp. nov., isolated from freshwater lake sediment. Int J Syst Evol Microbiol 55, 133-138.

Park, M. S., Jung, S. R., Lee, K. H., Lee, M. S., Do, J. O., Kim, S. B. \& Bae, K. S. (2006). Chryseobacterium soldanellicola sp. nov. and Chryseobacterium taeanense sp. nov., isolated from roots of sand-dune plants. Int J Syst Evol Microbiol 56, 433-438.

Peterson, W. J., Bell, T. A., Etchells, J. L. \& Smart, W. W. G., Jr (1954). A procedure for demonstrating the presence of carotenoid pigments in yeasts. $J$ Bacteriol 67, 708-713.

Quan, Z. X., Kim, K. K., Kim, M. K., Jin, L. \& Lee, S. T. (2007). Chryseobacterium caeni sp. nov., isolated from bioreactor sludge. Int $J$ Syst Evol Microbiol 57, 141-145.

Shen, F.-T., Kämpfer, P., Young, C.-C., Lai, W.-A. \& Arun, A. B. (2005). Chryseobacterium taichungense sp. nov., isolated from contaminated soil. Int J Syst Evol Microbiol 55, 1301-1304.
Shimomura, K., Kaji, S. \& Hiraishi, A. (2005). Chryseobacterium shigense sp. nov., a yellow-pigmented, aerobic bacterium isolated from a lactic acid beverage. Int J Syst Evol Microbiol 55, 19031906.

Stackebrandt, E. \& Ebers, J. (2006). Taxonomic parameters revisited: tarnished gold standards. Microbiol Today 33, 152-155.

Stackebrandt, E. \& Goebel, B. M. (1994). Taxonomic note: a place for DNA-DNA reassociation and 16S rRNA sequence analysis in the present species definition in bacteriology. Int J Syst Bacteriol 44, 846849.

Tai, C. J., Kuo, H. P., Lee, F. L., Chen, H. K., Yokota, A. \& Lo, C. C. (2006). Chryseobacterium taiwanense sp. nov., isolated from soil in Taiwan. Int J Syst Evol Microbiol 56, 1771-1776.

Tamura, K., Dudley, J., Nei, M. \& Kumar, S. (2007). MEGA4: molecular evolutionary genetics analysis (MEGA) software version 4.0. Mol Biol Evol 24, 1596-1599.

Vandamme, P., Bernardet, J.-F., Segers, P., Kersters, K. \& Holmes, B. (1994). New perspectives in the classification of the flavobacteria: description of Chryseobacterium gen. nov., Bergeyella gen. nov., and Empedobacter nom. rev. Int J Syst Bacteriol 44, 827-831.

Vaneechoutte, M., Kämpfer, P., De Baere, T., Avesani, V., Janssens, M. \& Wauters, G. (2007). Chryseobacterium hominis sp. nov., to accommodate clinical isolates biochemically similar to CDC groups II-h and II-c. Int J Syst Evol Microbiol 57, 2623-2628.

Weon, H. Y., Kim, B. Y., Yoo, S. H., Kwon, S. W., Cho, Y. H., Go, S. J. \& Stackebrandt, E. (2006). Chryseobacterium wanjuense sp. nov., isolated from greenhouse soil in Korea. Int J Syst Evol Microbiol 56, 1501-1504.

Yabuuchi, E., Kaneko, T., Yano, I., Moss, C. W. \& Miyoshi, N. (1983). Sphingobacterium gen. nov., Sphingobacterium spiritivorum comb. nov., Sphingobacterium multivorum comb. nov., Sphingobacterium mizutae sp. nov., and Flavobacterium indologenes sp. nov.: glucose nonfermenting Gram-negative rods in CDC groups IIK-2 and IIb. Int J Syst Bacteriol 33, 580-598.

Yoon, J. H., Kang, S. J. \& Oh, T. K. (2007). Chryseobacterium daeguense sp. nov., isolated from wastewater of a textile dye works. Int J Syst Evol Microbiol 57, 1355-1359.

Young, C. C., Kämpfer, P., Shen, F. T., Lai, W. A. \& Arun, A. B. (2005). Chryseobacterium formosense sp. nov., isolated from the rhizosphere of Lactuca sativa L. (garden lettuce). Int J Syst Evol Microbiol 55, 423426.

Zhou, Y., Dong, J., Wang, X., Huang, X., Zhang, K. Y., Zhang, Y. Q., Guo, Y. F., Lai, R. \& Li, W. J. (2007). Chryseobacterium flavum sp. nov., isolated from polluted soil. Int J Syst Evol Microbiol 57, 17651769. 